\title{
ISOLASI Escherichia coli PADA DAGING SAPI SEGAR YANG DIPEROLEH DARI BEBERAPA PASAR TRADISIONAL DI PEKANBARU
}

\author{
Elsie, Israwati Harahap
}

\author{
Program Studi Biologi, Fakultas MIPA, Universitas Muhammadiyah Riau, \\ Jln. Tuanku Tambusai Ujung No. 1 Pekanbaru 28285 \\ Email korespondensi: elsie@umri.ac.id
}

\begin{abstract}
Escherichia coli is a bacteria that inhabitant in the cattle or human intestine. Raw beef sold in the traditional markets is easily to contaminated by E. coli. It's because the markets is one of the vulnerable and the risk is high enough against contamination. The goal of this research is to detect E. coli contamination in the fresh raw beef at several markets in Pekanbaru. This research used $100 \mathrm{gr}$ fresh raw beef purchased from the six traditional markets in Pekanbaru. The study begins with a Most probable Number (MPN) test, than isolation and identification of the media ECB and L-EMB, initially with IMViC test (Indol, Methyl Red, Voges Praskauer and Citrate). Results of MPN test showed that all raw beef were contaminated E.coli with MPN varying value. Keywords: E.coli, fresh raw beef
\end{abstract}

\section{PENDAHULUAN}

Kebutuhan akan konsumsi daging sapi terus meningkat sejalan dengan pertambahan jumlah penduduk, perkembangan ekonomi, perubahan gaya hidup, kesadaran gizi, dan perbaikan tingkat pendidikan. Hal ini dikarenakan daging sapi sebagai protein hewani memiliki nilai gizi yang tinggi dengan komposisi $75 \%$ air, $18 \%$ protein, 3,5\% lemak dan 3,5\% zat-zat non protein yang dapat larut (Lawrie, 2003).

Daging sapi yang merupakan bahan pangan asal hewan memiliki potensi yang membahayakan yaitu bahaya biologis, fisik dan kimiawi (Nugroho, 2004). Contoh bahaya biologis yaitu disebabkan oleh bakteri patogen, hal ini dikarenakan daging merupakan media yang sangat baik untuk pertumbuhan bakteri tersebut. Sedangkan bahaya kimiawi ditimbulkan oleh adanya cemaran residu antibiotik, hormon, pestisida, dan bahaya fisik disebabkan oleh cemaran logam. Bahayabahaya tersebut dapat terjadi selama proses pemeliharaan ternak, proses penyediaan sejak penyembelihan hingga pemotongan dan proses pengolahan menjadi produk olahan. Berdasarkan ketiga jenis bahaya di atas penyebab utama terjadinya kerusakan daging adalah bahaya biologis yang disebabkan oleh bakteri patogen.
Salah satu bakteri yang dapat mengkontaminasi daging sapi secara eksogen ialah Escherichia coli (Rahadi, 2011). E. coli merupakan bakteri yang termasuk flora normal yang terdapat di saluran pencernaan ternak dan manusia. Strain E. coli yang bersifat patogen dan dapat menimbulkan infeksi dan foodborne disease adalah E.coli O157:H7 yang menghasilkan shiga toxin (Atalla et al. 2000).

Peningkatan keamanan pangan terhadap makanan asal hewan seperti daging sapi maupun olahannya mutlak perlu dilakukan. Hal ini untuk menjamin kualitas makanan yang dikonsumsi oleh masyarakat agar layak dan aman untuk dikonsumsi sehingga dapat mencegah dan menurunkan prevalensi food borne pathogens.

Daging sapi yang dijual di pasar tradisional sangat mudah terkontaminasi oleh bakteri $E$. coli. Hal ini dikarenakan pasar merupakan salah satu tempat yang rawan dan beresiko cukup tinggi terhadap cemaran mikroba patogen. Sanitasi dan kebersihan lingkungan penjualan belum mendapat perhatian baik dari pedagang itu sendiri maupun petugas terkait untuk meminimumkan tingkat cemaran mikroba. Tempat penjual daging sapi di pasar tradisional masih bercampur baur dengan penjual kebutuhan pokok yang lainnya, selain itu daging yang dijual hanya diletakkan pada meja dan digantung pada suhu kamar. 
Situasi pasar tradisonal dengan segala kegiatan dan kondisi lingkungannya memiliki potensi kontaminasi yang tinggi terhadap daging yang diperdagangkan. Penjualan daging di pasar tradisional umumnya dilakukan dalam keadaan terbuka (tanpa penutup). Daging disajikan di lokasi yang kurang terjamin kebersihannya dan bersuhu udara tinggi (suhu kamar). Pada kondisi tersebut mikroba patogen dapat tumbuh dengan subur.

Berdasarkan latar belakang di atas, maka perlu dilakukan penelitian tentang kontaminasi bakteri E. coli pada daging sapi di beberapa pasar tradisional yang ada di Kota Pekanbaru, sehingga dapat diketahui kelayakan daging sapi tersebut untuk dikonsumsi.

\section{METODOLOGI PENELITIAN}

Alat yang digunakan dalam penelitian ini adalah autoklaf (All American), vortex (Velp), inkubator (Memmert), rak tabung, timbangan analitik (Adventurer), stomacher (Stomacher lab blender 400), waterbath (Memmert), gunting, pinset, penangas air (Velp), alat-alat gelas (tabung durham, tabung reaksi, bunsen, cawan Petri, pipet ukur, dan gelas ukur).

Bahan yang digunakan adalah sampel daging sapi, aquades, Larutan Buffered Pepton Water (BPW), Escherichia Coli Broth (ECB), media Lactose Broth (LB), dan Levine Eosin Metylene Blue Agar (L-EMB), Tryptone Broth, MR-VP media, Koser Citrtat Broth (KCB), Nutrient Agar (NA), larutan Kovac, larutan merah metil, larutan alfa naftol, larutan $\mathrm{KOH}$ $40 \%$.

\section{Pengambilan Sampel}

Sampel yang digunakan adalah daging sapi segar yang dibeli dari beberapa pasar yang dikelola oleh dinas pasar Pekanbaru yaitu Pasar Cik Puan, Pasar Labuh Baru, Pasar Simpang Baru, Pasar Lima Puluh, Pasar H. Agus Salim, dan Pasar Rumbai. Sampel daging sapi diambil sebanyak 100 gram dari masing-masing pasar tradisional.

\section{Pengujian Most Probable Number (MPN)}

Daging sapi ditimbang seberat 10 gr, dimasukkan ke dalam kantong steril kemudian dihancurkan dengan alat stomacher selama 1 menit. Setelah itu dimasukkan ke dalam tabung reaksi yang berisi $90 \mathrm{ml}$ larutan BPW 0,1\% dan dihomogenkan dengan vortex selama 1 menit sampai dengan 2 menit. Dari larutan BPW 90 $\mathrm{ml}$ diambil sebanyak $1 \mathrm{ml}$ dengan menggunakan pipet mikro lalu dimasukkan ke dalam tabung reaksi yang berisi $9 \mathrm{ml}$ BPW (pengenceran $10^{-1}$ ). Pada pengenceran $10^{7}$ diambil $1 \mathrm{ml}$ dengan pipet steril dipindahkan ke dalam larutan $9 \mathrm{ml}$ BPW untuk mendapatkan pengenceran $10^{-2}$ dan dengan cara yang sama dibuat pengenceran $10^{-3}$.

\section{Uji IMViC}

Uji indol dilakukan dengan mengambil 1 ose biakan dari NA miring, kemudian diinokulasi ke dalam media Tryptone Broth. Inkubasi dilakukan pada suhu $35-37^{\circ} \mathrm{C}$ selama 24 jam. Setalah itu ke dalam media Tryptone Broth tersebut ditambahkan 0,2-0,3 ml larutan Kovac dan dihomogenkan. Pengamatan dilakukan setelah 10 menit. Reaksi positif akan terlihat dengan terbentuk cincin berwarna merah pada permukaan media.

Biakan dari NA miring diambil 1 ose kemudian diinokulasi pada media MR-VP untuk melakukan uji Methyl Red. Setelah itu diinkubasi pada suhu $35-37^{\circ} \mathrm{C}$ selama 48 jam, kemudian ditambahkan 5 tetes larutan metil merah pada tiap tabung biakan dan dikocok. Jika berubah warna menjadi merah maka hasil menunjukkan positif.

Untuk uji Voges Praskauer, diambil 1 ose bakteri dari biakan NA miring diinokulasi pada media MR-VP suhu $35-37^{\circ} \mathrm{C}$ selama 48 jam. Ditambahkan 0,6 $\mathrm{ml}$ larutan Alfa Naftol dan 0,2 ml larutan Kalium Hidroksida 40\% dikocok homogen. Jika terbentuk warna merah menunjukkan hasil yang positif.

Biakan NA miring diambil 1 ose, diinokulasikan pada media Simmon's Citrate agar untuk melakukan uji sitrat, kemudian diinkubasi pada suhu $35-37^{\circ} \mathrm{C}$ selama 48 jam, diamati pertumbuhan dan perubahan warna biakan. Reaksi yang positif akan terjadi perubahan warna dari hijau ke biru dan timbulnya kekeruhan. 


\section{Analisis Data}

Data yang diperoleh dari hasil penelitian dilaporkan secara deskriptif, disajikan dalam bentuk tabel dan narasi. Hasil perhitungan dilakukan sesuai dengan SNI: 01-6366-2000 yaitu $5 \times 10^{1} \mathrm{MPN} /$ gram untuk standar batas maksimal cemaran E. coli. Apabila melebihi batas tersebut berarti cemaran mikroorganisme tinggi dan apabila kurang dari batas tersebut berarti cemaran mikroorganisme rendah.

\section{HASIL DAN PEMBAHASAN}

\section{Pengujian MPN Pada Sampel Daging} Sapi

Enam sampel daging sapi yang diperoleh dari enam pasar tradisional yang ada di Pekanbaru diperiksa untuk mengetahui cemaran E.coli pada sampel daging tersebut (Tabel 4.1).

Tabel 4.1. Pemeriksaan E.coli pada Sampel

Daging Sapi

\begin{tabular}{|l|c|c|}
\hline \multicolumn{1}{|c|}{ Asal Sampel } & Nilai MPN & $\begin{array}{c}\text { SNI (01-6366- } \\
\text { 2000) }\end{array}$ \\
\hline Pasar Simpang Baru & $>1100$ & \multirow{3}{*}{$5 \times 10^{1} \mathrm{MPN} / \mathrm{g}$} \\
\hline Pasar Cik Puan & 11 & \\
\cline { 1 - 2 } Pasar Hj. Agus Salim & 21 & \\
\hline Pasar Labuh Baru & 7,2 & \\
\cline { 1 - 2 } Pasar Rumbai & 75 & \\
\hline Pasar Lima Puluh & 3 & \\
\hline
\end{tabular}

Hasil uji MPN menunjukkan bahwa seluruh daging sapi yang diperiksa telah tercemar E.coli dengan nilai MPN yang bervariasi. Nilai MPN E. coli pada sampel daging sapi yang berasal dari Pasar Simpang Baru yaitu $>1100$ dan Pasar Rumbai sebesar 75, nilai tersebut melebihi batas yang telah ditetapkan oleh SNI yaitu sebesar $5 \times 10^{1}$ $\mathrm{MPN} / \mathrm{g}$. Sedangkan empat sampel daging sapi yang berasal dari Pasar Cik Puan, Pasar Agus Salim, Pasar Labuh Baru dan Pasar Lima Puluh memiliki nilai MPN E.coli dibawah standar yang telah ditetapkan oleh SNI sehingga daging tersebut layak untuk dikonsumsi.

Tingginya cemaran E. coli pada sampel daging sapi yang terdapat di pasar tradisional di Pekanbaru diduga karena daging sapi telah tercemar oleh bakteri mulai dari RPH (Rumah Potong Hewan). Menurut Bahendra (2007), yang melakukan penelitian mengenai cemaran bakteri pada daging sapi yang dipotong di RPH
Kota Pekanbaru dan hasilnya menunjukkan bahwa cemaran bakteri melebihi batas maksimum yang direkomendasikan oleh SNI No. 01-6366-2000. Hal ini dikarenakan belum diterapkannya sanitasi dan higienitas pada RPH tersebut. Menurut standar SNI 01-6159-1999, bahwa tempat penyimpanan (box) pada kendaraan pengangkut daging harus tertutup dan dilengkapi dengan alat pendingin yang dapat mempertahankan suhu bagian dalam daging $7^{\circ} \mathrm{C}$. Potongan-potongan daging dikemas dalam plastik dan kotak, ditempatkan dan disimpan, dilengkapi dengan alat pendingin dan didistribusikan dalam keadaan dingin. Pengangkutan kendaraan daging seharusnya sesuai dengan SNI 01-6159-1999 agar bakteri tidak berkembang biak.

Selain itu, kontaminasi bakteri dapat terjadi pada saat proses pemotongan ternak, sebab proses pemotongan khususnya pengulitan dan pengeluaran jeroan merupakan titik paling rentan terhadap terjadinya kontaminasi dari bagian kulit dan isi saluran pencernaan (Buckle et al., 1987). Kontaminasi bakteri, di samping berasal dari bagian tubuh ternak sewaktu masih hidup, juga dapat berasal dari lingkungan sekitar tempat pemotongan. Salmonellosis merupakan salah satu kontaminan karkas dan daging yang berasal dari lingkungan sekitar tempat pemotongan (Soeparno, 2009). Faktor lain yang menyebabkan tingginya jumlah E.coli pada sampel daging sapi yaitu kurang bersihnya alat-alat yang digunakan pada saat pemotongan daging yang akan meningkatkan kontaminasi bakteri pada daging tersebut dan penempatan daging dapi yang dijual di pasar pada suhu ruang akan mempercepat pertumbuhan bakteri. E. coli sebagai mikroorganisme mesofilik akan tumbuh secara optimal pada suhu $20^{\circ}-40^{\circ} \mathrm{C}$ (Soeparno, 2005).

Bakteri patogen dapat ditularkan melalui makanan termasuk daging. Kadar air yang tinggi pada daging mengakibatkan bakteri dapat berkembang baik di daging sapi (Soeparno, 2009). Jenis-jenis bakteri yang sering ditemukan diantaranya, Salmonella, Shigella, E. coli, Vibrio cholerae, dan Vibrio parahaemolyticus. 
Semua sampel daging sapi positif tercemar E.coli. Hal ini dapat dilihat dari permukaan koloni yang berwarna hijau metalik pada medium L-EMB (Gambar 4.1). Eosin Methylene Blue Agar adalah media selektif dan diferensial. Media ini mengandung Eosin dan metilen biru, yang menghambat pertumbuhan bakteri Gram positif, maka media ini dipilih untuk bakteri Gram negatif. Warna media sebelum diinokulasi oleh bakteri berwarna merah keunguan. Perubahan warna hijau metalik pada media L-EMB karena E.coli dapat memfermentasi laktosa yang mengakibatkan peningkatan kadar asam dalam media. Kadar asam yang tinggi dapat mengendapkan metylen blue dalam media L-EMB (Lindquist, 2004).

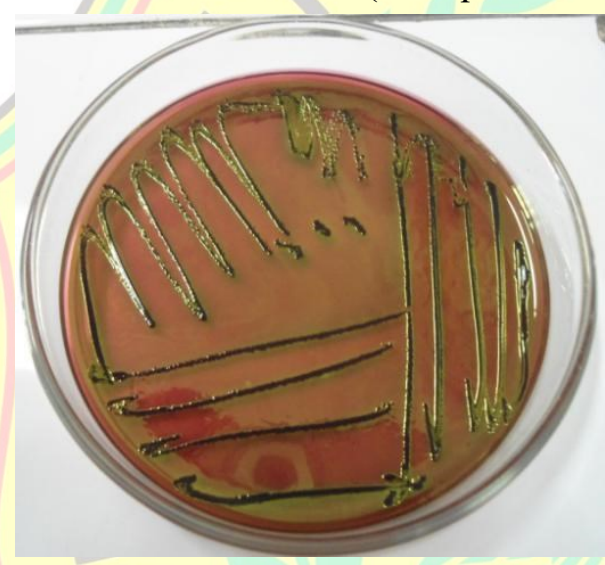

Gambar 4.1. Koloni E.coli pada media LEMB yang diinkubasi pada suhu $35^{\circ} \mathrm{C}$ selama 24 jam

\section{Hasil Uji IMViC}

Isolat E.coli yang telah berhasil diisolasi selanjutnya diidentifikasi dengan uji IMViC. Hasil reaksi positif E. coli yang mampu memproduksi indol ditandai dengan adanya bentuk cincin merah pada lapisan atas media (Gambar 4.2), sedangkan hasil yang negatif ditandai dengan terbentuknya cincin kuning pada media. Reagen Kovac merupakan larutan yang digunakan untuk uji indol. Warna cincin merah yang dihasilkan Reagen Kovac pada media TB merupakan indikator keberadaan $E$. coli. Perubahan ini karena Reagen Kovac mengandung p-dimetilbenzaldehid yang merupakan indikasi bakteri mampu memecah senyawa asam amino triptofan menjadi senyawa para amino benzaldehid yang tidak larut air.

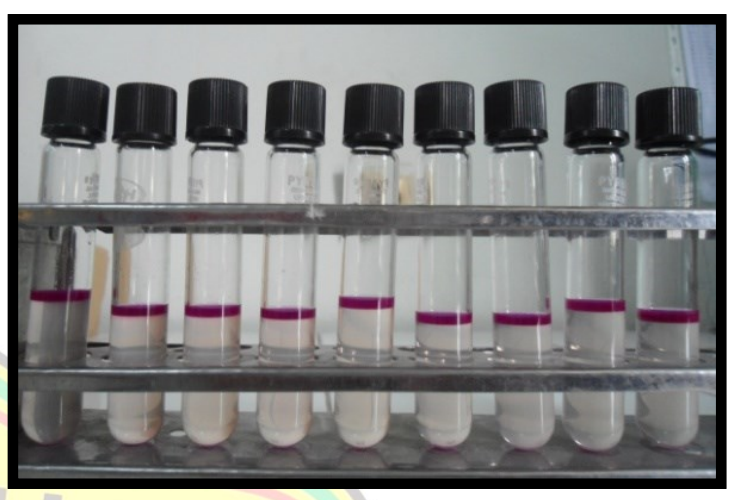

Gambar 4.2. Uji Indol Pada Isolat E.coli

Hasil uji MR yang positif ditandai dengan adanya warna merah (Gambar 4.3) setelah diteteskan indikator MR dan hasil reaksi negatif ditandai dengan adanya warna kuning. Uji MR digunakan untuk mendeteksi kemampuan suatu organisme untuk menghasilkan dan mempertahankan produk asam yang stabil dari fermentasi glukosa. MR adalah indikator $\mathrm{pH}$, yang tetap berwarna merah pada $\mathrm{pH} 4,4$ atau kurang.

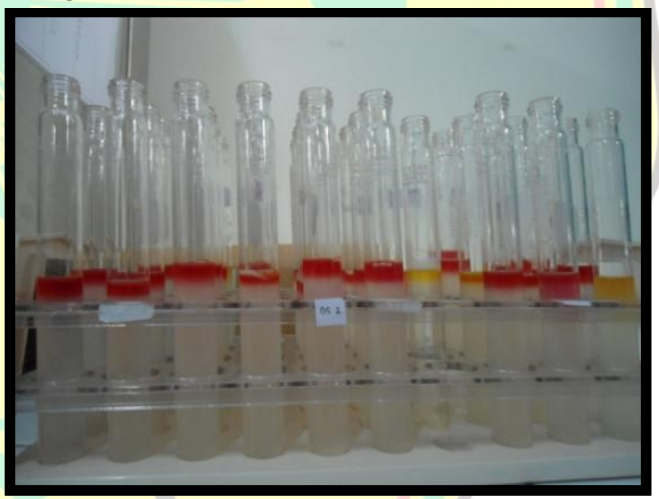

Gambar 4.3. Uji MR pada isolat E.coli

Hasil uji VP akan terlihat setelah ditambahkannya $0,6 \mathrm{ml}$ larutan $\alpha$-naphthol dan $0,2 \mathrm{ml} \mathrm{KOH} 40 \%$. Hasil reaksi positif ditandai dengan adanya warna merah muda dalam waktu 2 jam. Uji VP digunakan untuk mendeteksi kemampuan organisme dalam menghasilkan glikon butilena. Asetil-metil karbinol (acetoin) adalah perantara dalam produksi butilen glikol. Untuk mendeteksi E. coli pada uji VP ditunjukkan pada hasil yang negatif dengan warna kuning pada media VP (Gambar 4.4). 


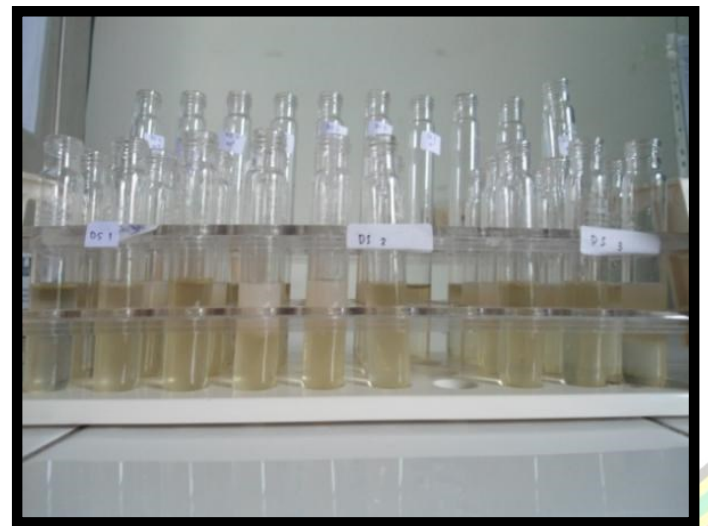

Gambar 4.4. Uji VP pada isolat E.coli

Hasil uji citrate akan terlihat setelah media diinkubasi selama 96 jam pada suhu $35^{\circ} \mathrm{C}$. Hasil uji yang positif ditandai dengan terbentuknya kekeruhan pada media. Hasil uji yang negatif tidak terbentuk nya kekeruhan pada media. Untuk mendeteksi E. coli pada uji citrate ditunjukkan pada hasil uji yang negatif tidak terbentuknya kekeruhan atau berwarna bening (Gambar 4.5).

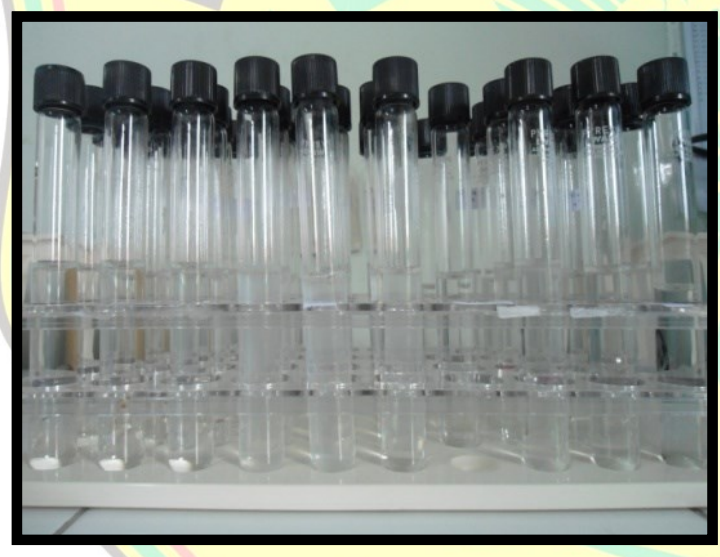

Gambar 4.5. Uji Citrate pada isolat E.coli

\section{KESIMPULAN DAN SARAN}

Berdasarkan penelitian yang telah dilakukan diperoleh bahwa sampel daging sapi yang berasal dari pasar Simpang Baru dan Pasar Rumbai memiliki nilai MPN sebesar $>1100$ MPN/g dan $75 \mathrm{MPN} / \mathrm{g}$ dan nilai tersebut melebihi batas yang telah ditetapkan oleh SNI sebesar $5 \times 10^{1} \mathrm{MPN} / \mathrm{g}$. Sedangkan nilai MPN pada sampel daging sapi asal Pasar Cik Puan, Pasar Agus Salim, Pasar Labuh Baru dan Pasar Lima Puluh berturut-turut sebesar $11 \mathrm{MPN} / \mathrm{g}$, $21 \mathrm{MPN} / \mathrm{g}, 7,2 \mathrm{MPN} / \mathrm{g}$ dan $3 \mathrm{MPN} / \mathrm{g}$.
Diperlukan upaya pemerintah untuk melakukan pembinaan dan pengawasan kepada para pedagang daging sapi untuk menjaga kebersihan daging sapi mulai dari RPH sampai di jual di pasar, selain itu kondisi pasar harus sesuai dengan kebijakan tata letak ruang yang ditetapkan oleh pengelola pasar. Hal ini agar masyarakat mendapatkan daging sapi yang bekualitas baik, serta memperbaiki fasilitas dan memaksimalkan peran distribusi daging sapi dengan menekankan program higienis dan sanitasi agar kontaminasi daging sapi tidak melebihi standar yang telah ditentukan.

\section{DAFTAR PUSTAKA}

Atalla HN, Johnson R, McEwen S, Usborne RW, Gyles CL. 2000. Use of Shiga Toxin (Stx) Enzyme Linked Immunosorbent Assay and Immunoblot for Detection and Isolation of Stx Producing Escherichia coli from Naturally Contaminated Beef. Journal of Food Protection. 63(9): 1167-1172.

Bahendra. 2007. Kualitas Daging Sapi Bali (Bos sundaicus) di Rumah Potong Hewan Kota Pekanbaru. Skripsi Fakultas Pertanian dan Peternakan Universitas Islam Negeri Sultan Syarif Kasim Riau.

Buckle, K. A., Edward, R. A., Fleet, G. H., Wooton, M. 1987. Ilmu Pangan. Purnomo H, Adiono, penerjemah. Jakarta: UI Press. Terjemahan dari: Food Science.

Nugroho, S. 2004. Jaminan Keamanan Daging di Indonesia. Bogor: Institut Pertanian Bogor.

Lawrie R.A. 2003. Ilmu Daging. Aminuddin P, penerjemah. Jakarta: UI-Press. Terjemahan dari : Meat Science. Daging. Yogyakarta: Universitas Gadjah Mada.

Rahadi, USE. 2011. Isolasi E.coli dari Daging

Sapi yang Dijual di Pasar Tradisional Surabaya Selatan. Artikel Ilmiah.

Soeparno. 2009. Ilmu dan Teknologi Daging. Fakultas Peternakan Universitas Gajah Mada. Yogyakarta: University Press. 